\title{
ERRATUM
}

\section{The hard cell(s) of avian transgenesis}

\author{
Robert J. Etches
}

Published online: 14 November 2006

(C) Springer Science+Business Media B.V. 2006

\section{Erratum to: Transgenic Res}

\section{DOI: 10.1007/s11248-006-9018-2}

Due to an unfortunate error a distorted version of Figure 1 has been used in the above mentioned publication. On the following page, the correct

reproduction has been published which should be treated as definitive by the reader.

The online version of the original article can be found at http://dx.doi.org/10.1007/s11248-006-9018-2

R. J. Etches $(\square)$

Origen Therapeutics, 1450 Rollins Road, Burlingame, CA 94010, USA

e-mail: retches@origentherapeutics.com 


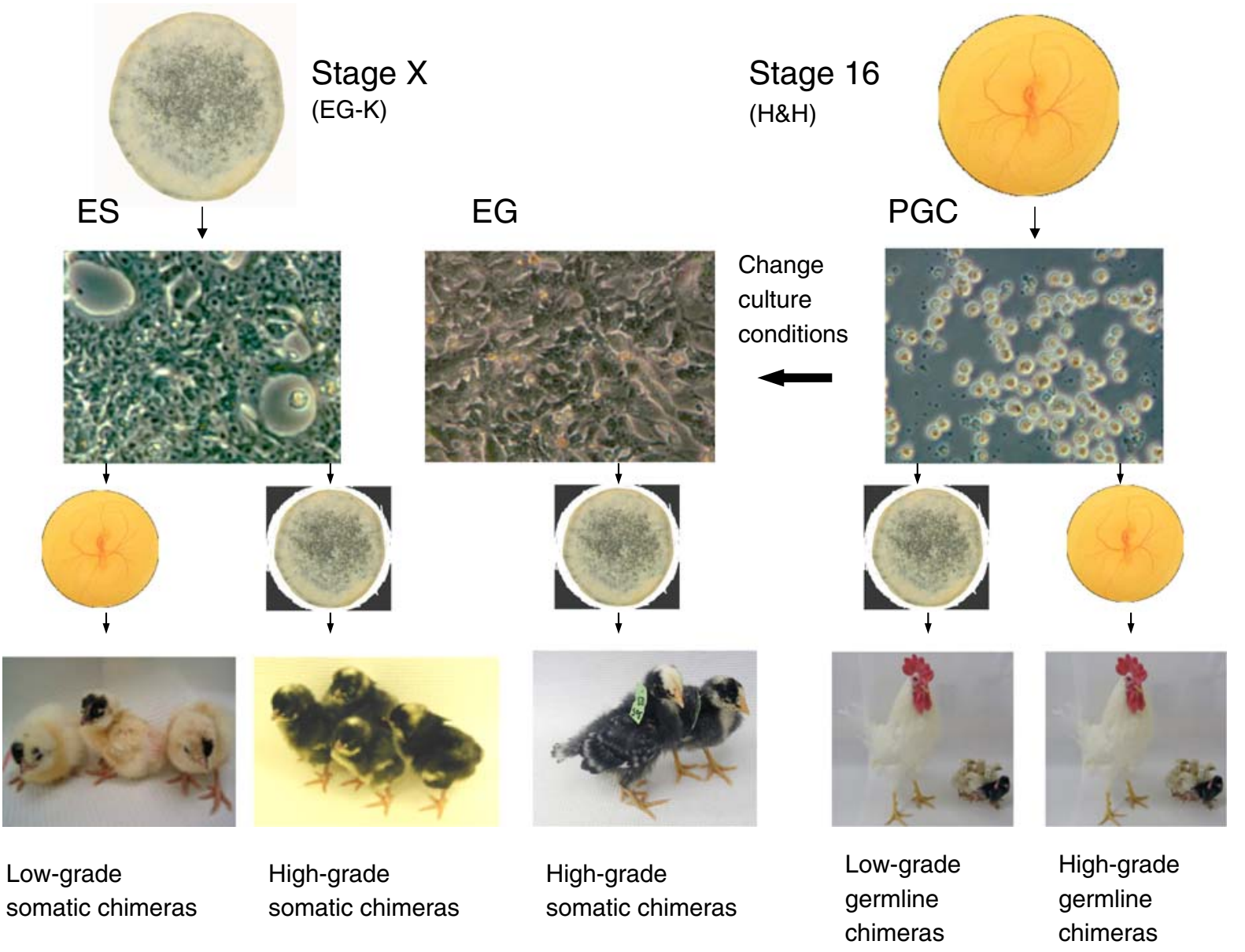

Fig. 1 The interrelationships between embryonic stem (ES) cells, embryonic germ (EG) cells and primordial germ cells (PGCs). ES cells are derived from the area pellucida of Stage X (Eyal-Giladi and Kochav 1976) embryos in newly laid, fertile eggs. When injected into a Stage $\mathrm{X}(\mathrm{EG} \& \mathrm{~K})$ recipient embryo, ES produce highgrade somatic chimeras. When injected into Stage 14-16 (Hamburger and Hamilton 1951) embryos, they produce low-grade somatic chimeras. PGCs are derived from blood taken from Stage 14-16 (H\&H) embryos. When injected into Stage 14-16 $(\mathrm{H} \& \mathrm{H})$ recipient embryos, they produce germline chimeras that transmit at high rates. When injected into Stage $\mathrm{X}$ (EG\&K) embryos, they produce germline chimeras that transmit at low rates. PGCs do not contribute to somatic tissues in either Stage $14-16(\mathrm{H} \& \mathrm{H})$ or Stage $\mathrm{X}(\mathrm{EG} \& \mathrm{~K})$ recipients. When the culture conditions for PGCs are altered to resemble those of ES cells, PGCs differentiate into EG cells. EG cells resemble ES cells morphologically and functionally 